\title{
Antiproliferative Effect of Lenvatinib on Human Liver Cancer Cell Lines In Vitro and In Vivo
}

\author{
SACHIKO OGASAWARA ${ }^{1}$, YUTARO MIHARA ${ }^{1}$, REIICHIRO KONDO ${ }^{1}$, \\ HIRONORI KUSANO $^{1}$, JUN AKIBA ${ }^{2}$ and HIROHISA YANO ${ }^{1}$ \\ ${ }^{1}$ Department of Pathology, Kurume University School of Medicine, Kurume, Japan; \\ ${ }^{2}$ Department of Diagnostic Pathology, Kurume University Hospital, Kurume, Japan
}

\begin{abstract}
Background/Aim: Lenvatinib is a potent inhibitor of receptor tyrosine kinases, targeting vascular endothelial growth factor receptors (VEGFR1-3), fibroblast growth factor receptors (FGFRI-4), KIT, and RET. Here, we investigated the antiproliferative effects of lenvatinib in liver cancer cells in vitro and in vivo. Materials and Methods: Eleven hepatocellular carcinoma cell lines and two combined hepatocellular/cholangiocarcinoma cell lines were treated with 0-30 $\mu \mathrm{M}$ lenvatinib. Cell growth, apoptosis and the expression of FGFR1-4, FGF19, fibroblast growth factor receptor substrate (FRS) $2 \alpha$ and RET were examined. Two $H C C$ cell lines were subcutaneously implanted on nude mice and mice were treated with 3, 10, 30 mg/kg/day of lenvatinib or vehicle for 14 consecutive days. Tumor volume was measured every 3 days. Mice were sacrificed on day 15 and tumors were processed for histological examination. Blood vessels, microvessel density, necrosis, and apoptosis were also examined. Results: Lenvatinib dose- and timedependently inhibited growth of all cell lines; however, sensitivity to lenvatinib varied. Apoptosis was not observed in any cell line, and expression of FGFR1, -2, -3 and -4, $F G F 19, F R S 2 \alpha$, and RET were observed in these cell lines. Cell lines with high expression of these factors showed higher response to lenvatinib. In mice, lenvatinib dosedependently suppressed tumor growth. Blood vessels and microvessel density were significantly reduced and the rate of necrosis was significantly increased by lenvatinib; apoptosis was not observed. Conclusion: Antiproliferative effects of lenvatinib on liver cancer cells were observed in vitro and in vivo. Lenvatinib may suppress tumor formation
\end{abstract}

Correspondence to: Sachiko Ogasawara, Department of Pathology, Kurume University School of Medicine, 67 Asahi-machi, Kurume, Fukuoka 830-0011, Japan. E-mail: sachiko@med.kurume-u.ac.jp

Key Words: Liver cancer, tyrosine kinase inhibitor, lenvatinib, angiogenesis, fibroblast growth factor. by inhibiting angiogenesis, and via an additional direct antiproliferative effect in some liver cancer cells.

Liver cancer is one of the most prevalent and leading causes of cancer-related mortality worldwide, and has a high incidence in Asia (1). Hepatocellular carcinoma (HCC) accounts for approximately $90 \%$ of primary liver cancer (2). The major risk factors for HCC are chronic viral hepatitis (type $\mathrm{B}$ and $\mathrm{C}$ ), excessive alcohol consumption, and exposure to aflatoxin and the contributions of these factors may vary depending upon geographical location.

The progression of $\mathrm{HCC}$ is associated with growth factors such as vascular endothelial growth factor (VEGF), plateletderived growth factor (PDGF), and fibroblast growth factor (FGF) (3). Sorafenib, an oral multi-kinase inhibitor targeting RAF kinase, VEGF receptors (VEGFR1-3), PDGF receptor (PDGFR), fms-like tyrosine kinase 3, RET, and KIT $(4,5)$, was approved for first-line treatment of advanced HCC in 2007. However, the objective response rate (ORR) is low, and several studies have reported substantial toxicities associated with sorafenib $(6,7)$. Therefore, alternative therapies that are less toxic and more efficacious are necessary. Although several tyrosine kinase inhibitors (TKIs) have been compared to sorafenib in clinical studies of patients with advanced HCC, the clinical trials did not show non-inferiority (8-10) or superiority (11) in prolonging survival when used as first-line treatment of HCC.

Lenvatinib is an oral multi-kinase inhibitor that targets VEGFR1-3, FGFR1-4, PDGFR, RET, and KIT and has shown antitumor activity against advanced solid tumors $(5$, 12,13). Lenvatinib has shown promising antitumor effect for the treatment of radioiodine-refractory differentiated thyroid cancer and is approved in more than 50 countries including the United States, Japan, and Europe.

The phase III trial of lenvatinib demonstrated an effect on the overall survival (OS) of 954 patients with previously untreated unresectable HCC tumors by statistical confirmation of non-inferiority when compared to sorafenib 
(14). In this study, lenvatinib demonstrated statistically significant superiority in progression-free survival, time to progression, and ORR and was approved for the treatment of HCC in Japan, the United States, Europe, South Korea and China in 2018.

In this study, we examined: i) The antiproliferative effects of lenvatinib on liver cancer cell lines in vitro and in vivo; ii) the protein expression of growth-related factors in liver cancer cells; and iii) the mechanism of action of lenvatinib in liver cancer cells.

\section{Materials and Methods}

Cell lines and reagents. This study utilized $11 \mathrm{HCC}$ cell lines (KIM1, KYN-1, KYN-2, KYN-3, HAK-1A, HAK-1B, HAK-2, HAK-3, HAK-4, HAK-5 and HAK-6) and two combined hepatocellularcholangiocarcinoma cell lines (KMCH-1 and $\mathrm{KMCH}-2)$. These cell lines were originally established in our laboratory, and each cell line retains the morphological and functional features of the original tumor as described elsewhere (15-22). The cells were grown in Dulbecco's modified Eagle's medium (Nissui Pharmaceutical, Co., Tokyo, Japan) supplemented with $2.5 \%$ heat-inactivated $\left(56^{\circ} \mathrm{C}, 30\right.$ min) fetal bovine serum (Bioserum, Victoria, NSW, Australia), 100 $\mathrm{u} / \mathrm{ml}$ penicillin, $100 \mu \mathrm{g} / \mathrm{ml}$ streptomycin (GIBCO BRL/Life Technologies, Inc., Gaithersburg, MD, USA) and $12 \mathrm{mmol} / \mathrm{l}$ sodium bicarbonate, in an incubator with humidified atmosphere containing $5 \% \mathrm{CO}_{2}$ at $37^{\circ} \mathrm{C}$. Lenvatinib was supplied from Eisai, Tokyo Japan.

Effects of lenvatinib on the proliferation of liver cell lines in vitro. The cells $\left(2-10 \times 10^{3}\right.$ cells per well) were seeded in 96-well plates (Thermo Fisher Science, Roskilde, Denmark), cultured for $24 \mathrm{~h}$, and the culture medium was changed to a new medium with or without lenvatinib at $1.875,3.75,7.5,15$ and $30 \mu \mathrm{M}$. After culturing for 24 , 48 , or $72 \mathrm{~h}$, the number of viable cells was examined using the MTT cell growth assay kit (International Inc., Temecula, CA, USA). The $50 \%$ inhibitory concentration $\left(\mathrm{IC}_{50}\right)$ for each cell line was estimated after $72 \mathrm{~h}$ of culture with lenvatinib.

Quantitative analysis of lenvatinib-induced apoptosis in vitro. Cells cultured with or without lenvatinib $(7.5$ and $30 \mu \mathrm{M})$ for $48 \mathrm{~h}$ were stained using the Annexin V-EGFP Apoptosis Detection Kit (Medical \& Biological Laboratories, Co., Ltd, Nagoya, Japan), according to the manufacturer's protocol. After staining, cells were analyzed using the FACS Aria II flow cytometer (Becton Dickinson Immunocytometry Systems, San Jose, CA, USA), and the annexin V-EGFP-positive apoptotic cells were quantified.

Expression of growth-related factors in liver cancer cell lines. Western blot analysis was performed according to previously described methods (23). To examine the expression of growth-related factors, a sample ( $20 \mu \mathrm{g}$ total protein per lane) was resolved by Any $\mathrm{kD}^{\mathrm{TM}}$ Mini-PROTEAN TGX Precast acrylamide gels (Bio-Rad, Hercules, CA, USA). The proteins were transferred to PVDF membranes (Merck, Darmstadt, Germany), which were incubated with primary antibodies against the following: FGFR1 (D8E4, 1:1000; Cell Signaling, Beverly, MA, USA), FGFR2 (D4L2V, 1:1000; Cell Signaling), FGFR3 [EPR2305(3), 1:10000; Abcam, Cambridge, MA, USA], FGFR4 (D3B12, 1:1000; Cell Signaling), FRS2 (462910, 1:500; R\&D Systems, Minneapolis, MN, USA),
FGF19 (D1N3R, 1:1000; Cell Signaling), RET (E1N8X, 1:1000; Cell Signaling) and $\beta$-actin (AC-15, 1:2000; Sigma-Aldrich, St. Louis, MO, USA). Blots were detected with ImmunoStar LD (Wako Pure Chemical Ind., Tokyo, Japan). Immunoreactive bands were visualized by using FluorChem ${ }^{\mathrm{TM}}$ FC3 (ProteinSimple, San Jose, CA, USA).

Effects of lenvatinib on tumor formation of HCC cell lines in nude mice. KYN-2 cells $\left(8 \times 10^{6}\right.$ cells $\left./ 100 \mu \mathrm{l}\right)$ or HAK-1B cells $\left(8 \times 10^{6}\right.$ cells/100 $\mu \mathrm{l}$ ) were transplanted subcutaneously into the backs of 4week-old female BALB/c nude mice. After tumor formation was confirmed, the mice were divided into four groups ( $\mathrm{n}=6$ per group) and treated with 3,10 , or $30 \mathrm{mg} / \mathrm{kg} / \mathrm{day}$ of lenvatinib or vehicle (control) administered orally for 14 consecutive days. The tumor size was measured in two directions using calipers (until day 15), and tumor volume $\left(\mathrm{mm}^{3}\right)$ was estimated using the equation [length $\times(\text { width })^{2} \times 0.5$ ] on every 3 days. On day 15 , the mice were sacrificed and the resected tumors were weighed before formalin fixation. Paraffin sections were prepared for histological analysis.

Histological analysis. Paraffin sections were stained with hematoxylin-eosin. The terminal deoxynucleotidyl transferase (Tdt)mediated nick end labeling (TUNEL) technique (Apoptag Peroxidase In Situ Apoptosis Detection kit; Chemicon International Inc., Temecula, CA, USA) was used to detect apoptotic cells. Immunohistochemical staining with anti-mouse CD34 (Rat monoclonal, MEC14.7, 1:50 dilution; Abcam) was performed by standard avidin-biotin-peroxidase complex method and 3,3'diaminobenzidine solution was used for color development. To quantify the number of blood vessels and microvessel density (MVD), the slides were stained with antibody to CD34. Under microscopy, five areas were selected at a high power $(\times 200)$, and the number of blood vessels and the MVD in each specimen were measured using the WinROOF software package (version 6.1; Mitani Corporation, Fukui, Japan). The slides stained with hematoxylin-eosin were photographed using a loupe in the image and necrosis in the entire tumor was analyzed using the WinROOF software package.

Statistical analysis. Data are expressed as the mean \pm standard deviation (SD). Comparisons between groups were performed using Student's $t$-test and two-way factorial analysis of variance (ANOVA); $p<0.05$ was considered significant.

Ethics statement. This study was approved by the Ethics Committee of Kurume University (approval 2017\#319). Animal experiments for this study were approved by the Ethics Review Committee for Animal Experimentation of Kurume University School of Medicine (approval 2017\#217), according to guidelines created on the basis of the 'Guide for the Care and Use of Laboratory Animals' prepared by the National Academy of Sciences and published by the National Institutes of Health (NIH publication 86-23 revised 1985).

\section{Results}

Effects of lenvatinib on the proliferation of liver cell lines in vitro. In all cell lines, a time-dependent antiproliferative effect was observed to various degrees upon treatment with lenvatinib for 24,48 and $72 \mathrm{~h}$ in comparison to the control (Figure 1A). A decrease in cell viability of at least $20 \%$ was 

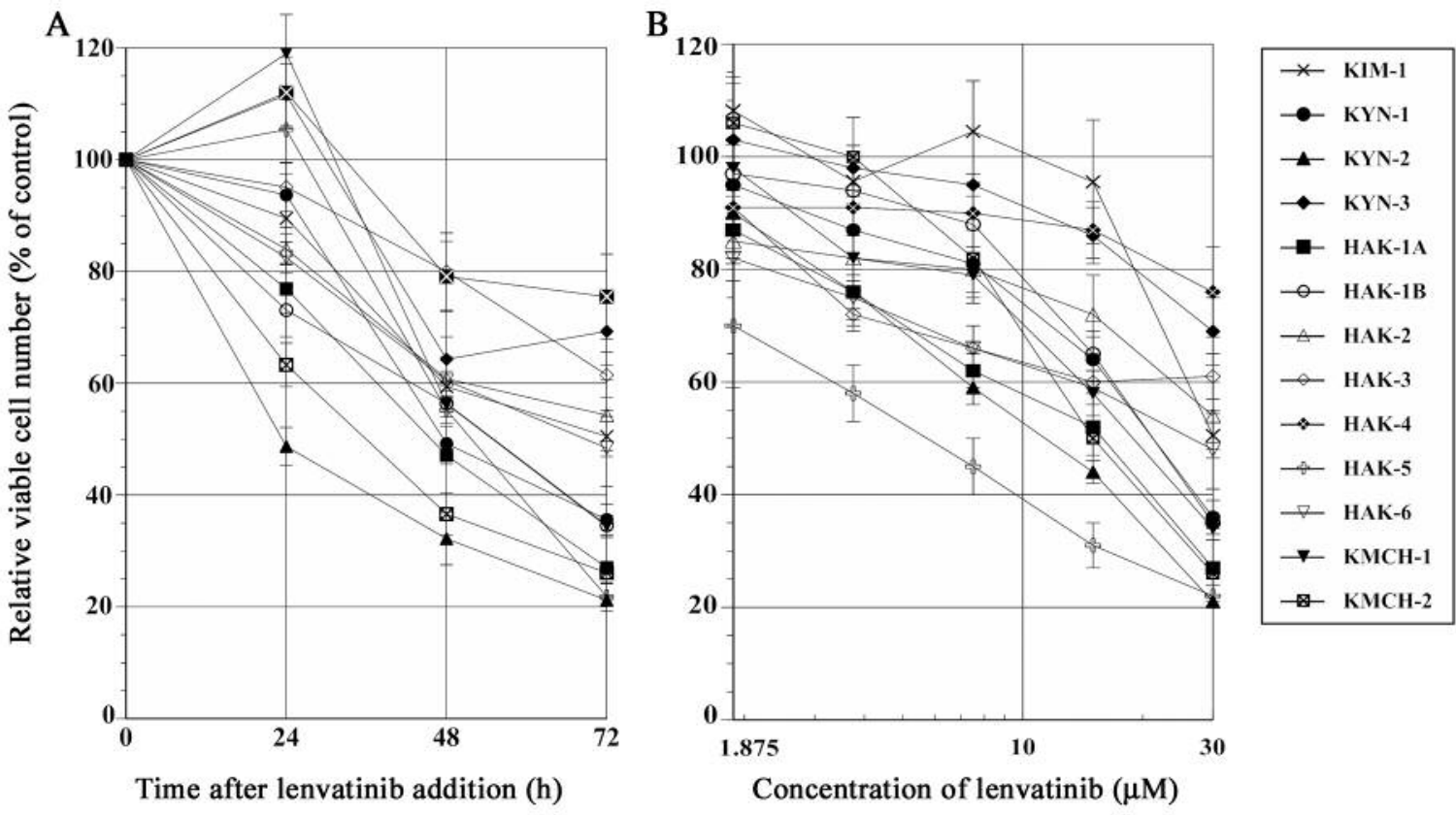

Figure 1. Antiproliferative effect of lenvatinib. A: Chronological changes in relative viable cell number (\% of the control) after adding $30 \mu M$ of lenvatinib. B: Relative viable cell number $72 \mathrm{~h}$ after adding 1.875, 3.75, 7.5, 15, or $30 \mu M$ of lenvatinib. Figures represent the average \pm SD.

observed in all 13 cell lines after $72 \mathrm{~h}$ of $30 \mu \mathrm{mol} / 1$ lenvatinib treatment. After $72 \mathrm{~h}$, the relative number of viable cells decreased in every cell line in a dose-dependent manner (Figure 1B). The number of viable cells at $72 \mathrm{~h}$ decreased to $<50 \%$ of the control in eight cell lines and the $\mathrm{IC}_{50}$ of lenvatinib was $5.8 \mu \mathrm{M}$ for HAK-5, $10.4 \mu \mathrm{M}$ for $\mathrm{KYN}-2,12.5 \mu \mathrm{M}$ for HAK-1A, $15.4 \mu \mathrm{M}$ for $\mathrm{KMCH}-2$, $18.2 \mu \mathrm{M}$ for $\mathrm{KMCH}-1,20.3 \mu \mathrm{M}$ for $\mathrm{KYN}-1,20.4 \mu \mathrm{M}$ for HAK-1B, and $28.5 \mu \mathrm{M}$ for HAK-6.

Quantitative analysis of lenvatinib-induced apoptosis in vitro. In all cell lines, quantitative analysis of apoptosis revealed that lenvatinib did not induce an increase in the amount of apoptosis in vitro (Figure 2).

Expression of growth-related factors in liver cancer cell lines. The protein expression of FGFR1-4 and FRS2 $\alpha$ varied among cell lines (Figure 3). The expression of FGF19 was observed only in KYN-2 and HAK-6, and the expression of RET was observed in HAK-5.

The protein expression of FGFR1, FGFR2, FGFR3, FGFR4, FGF19, FRS2 $\alpha$, and RET was clearly observed in 11 cell lines (all except KYN-1 and HAK-1A), five (KIM-1, KYN-2, HAK-1A, HAK-1B, and KMCH-2), nine (all except KIM-1, KYN-1, HAK-2, and HAK-6), 10 (except HAK-1A, HAK-3, and HAK-4), two (KYN-2 and HAK-6), 13, and 1 (HAK-5), respectively, of the 13 cell lines analyzed.
Effects of lenvatinib on tumor formation of HCC cell line in nude mice. Lenvatinib dose-dependently suppressed tumor growth in nude mice subcutaneously implanted with KYN2 and HAK-1B HCC cell lines. The average volume of each KYN-2 tumor in mice receiving 3, 10 , and $30 \mathrm{mg} / \mathrm{kg}$ of lenvatinib decreased to $37 \%(p<0.05), 29 \%(p<0.01)$, and $20 \%(p<0.01)$, respectively, compared to the control (Figure $4 \mathrm{~A})$. Tumor weights after 3,10 , and $30 \mathrm{mg} / \mathrm{kg}$ of lenvatinib also decreased by $50 \%, 27 \%(p<0.05)$, and $22 \%(p<0.05)$, respectively (Figure 4B). In addition, the average volume of each HAK-1B tumor in mice receiving 3,10, and $30 \mathrm{mg} / \mathrm{kg}$ of lenvatinib decreased to $61 \%, 32 \%(p<0.01)$, and $17 \%$ $(p<0.01)$, respectively (Figure $4 \mathrm{~A})$ with tumor weights also decreasing by $74 \%, 42 \%(p<0.01)$, and $40 \%(p<0.01)$, respectively (Figure $4 \mathrm{~B}$ ). Lenvatinib administration did not affect the body weights of mice (data not shown).

Histological analysis. Lenvatinib did not induce apoptosis of KYN-2 and HAK-1B HCC cells in vivo (Figure 5). The number of blood vessels and the MVD per unit area decreased as the concentration of lenvatinib increased (Figure 6). In the KYN-2 cell transplant model, the number of blood vessels in mice receiving 3,10 , and 30 $\mathrm{mg} / \mathrm{kg}$ of lenvatinib decreased to $72 \%(p<0.01), 39 \%$ $(p<0.001)$, and $21 \%(p<0.001)$, respectively (Figure 7A) compared to the control and the MVD under the same treatment condition decreased to $90 \%, 14 \%(p<0.01)$, and 


\section{Control}

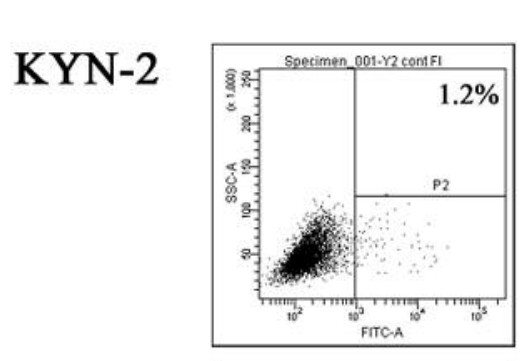

HAK-1B

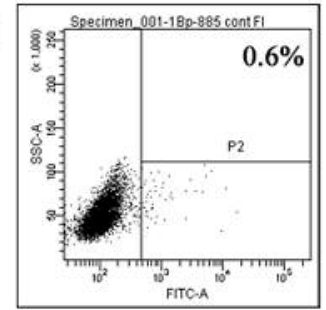

HAK-5

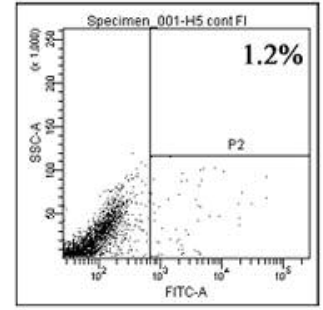

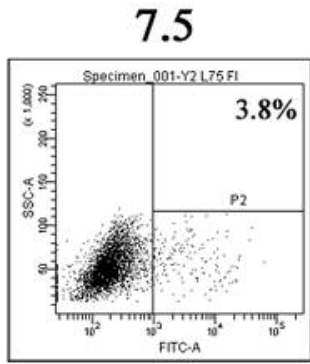
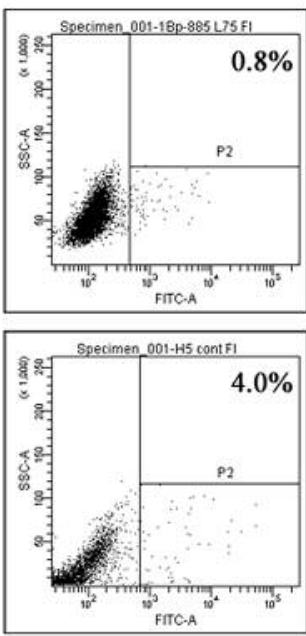

30
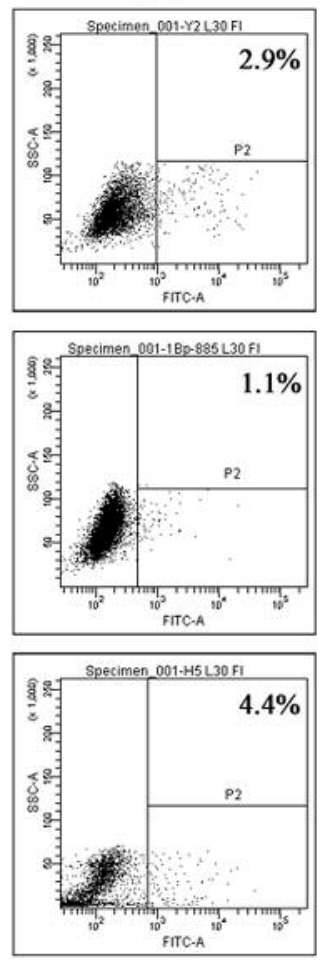

Figure 2. Quantitative analysis of lenvatinib-induced apoptosis cells in vitro. Representative data of three cell line experiments are shown.

$6 \%(p<0.01)$, respectively (Figure $7 \mathrm{~B})$. The rate of necrosis was significantly increased by lenvatinib in a dose-dependent manner in mice implanted with $\mathrm{KYN}-2$ cells and treated with lenvatinib (control vs. $10 \mathrm{mg} / \mathrm{kg}$ or $30 \mathrm{mg} / \mathrm{kg}, p<0.05$ ) (Figure 7C). In HAK-1B-transplanted mice, the number of blood vessels in mice receiving 3,10 , and $30 \mathrm{mg} / \mathrm{kg}$ of lenvatinib decreased to $59 \%(p<0.01)$, $29 \%(p<0.001)$, and 27\% ( $p<0.001)$, respectively (Figure 7A), and the MVD under the same treatment decreased to $48 \% \quad(p<0.05), 19 \% \quad(p<0.01)$, and $1 \% \quad(p<0.01)$, respectively (Figure $7 \mathrm{~B}$ ). The rate of necrosis of transplanted HAK-1B cells increased by more than twofold with 3,10 , and $30 \mathrm{mg} / \mathrm{kg}$ lenvatinib treatment $(p<0.05)$ compared with the control (Figure 7C).

\section{Discussion}

In this study, we examined the effect of lenvatinib on cell proliferation in vitro using 13 different cell lines of liver cancer. There was a suppression of cell proliferation in response to lenvatinib in all the cell lines tested. However, the sensitivity varied among the cell lines. The $\mathrm{IC}_{50}$ values

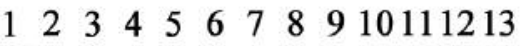

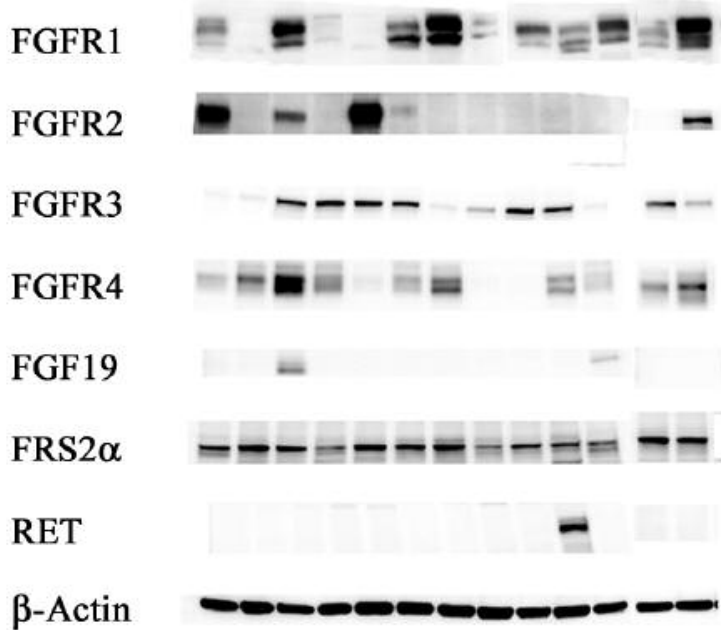

Figure 3. Western blot analysis of fibroblast growth factor receptor 1 4, FGF19, fibroblast growth factor receptor substrate $2 \alpha$, and RET in different liver cancer cell lines. Lane 1: KIM-1, 2: KYN-1, 3: KYN-2, 4: KYN-3, 5: HAK-1A, 6: HAK-1B, 7: HAK-2, 8: HAK-3, 9: HAK-4, 10: $H A K-5,11: H A K-6,12: K M C H-1,13: K M C H-2$. 
A

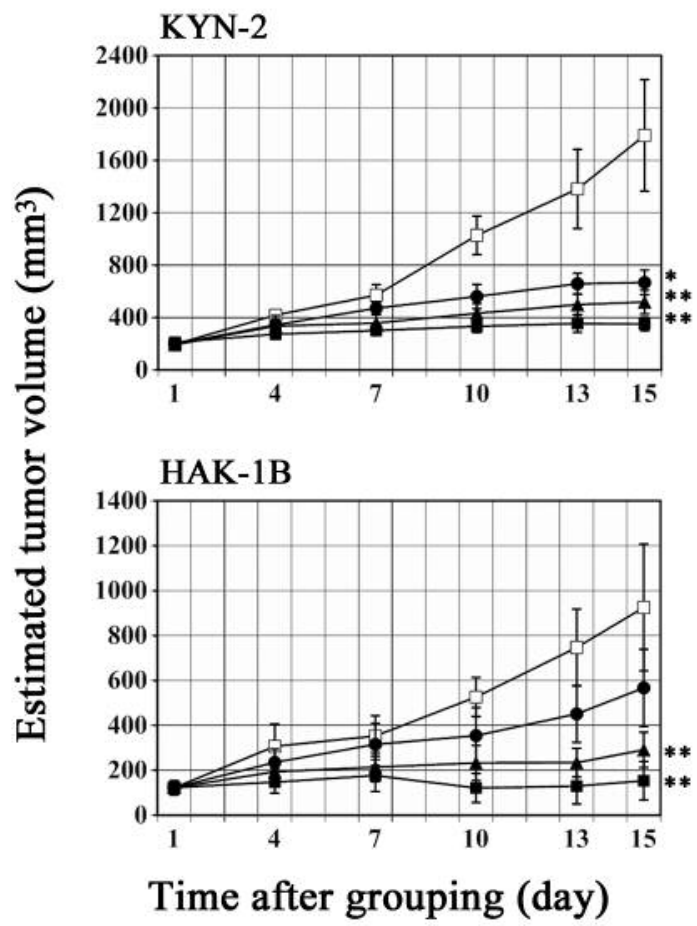

B
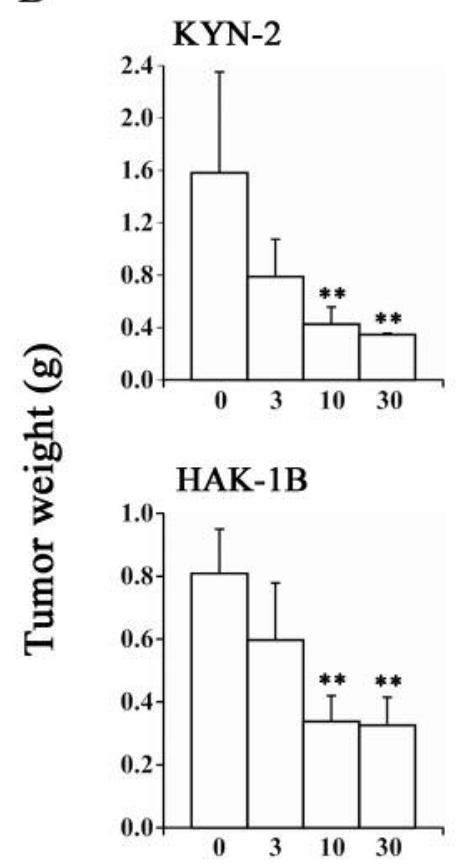

Lenvatinib $(\mathrm{mg} / \mathrm{kg})$

Figure 4. Antitumor effect of lenvatinib on tumors developed after subcutaneous transplantation of KYN-2 and HAK-1B cells in nude mice. A: Estimated volume of tumors generated by subcutaneously implanted HCC cells over a time course. The mice received $3(\boldsymbol{\bullet}), 10(\mathbf{\Delta})$, or 30 $m g / k g / m o u s e / d a y(\square)$, lenvatinib or vehicle (control) $(\square)$. B: All mice were sacrificed on day 15, and tumor weight was measured. Figures represent the average $\pm S D$. Significantly different at $* p<0.05$ or $* * p<0.01$ vs. control.

ranged between 5.8 and $28.5 \mu \mathrm{M}$ in $8 / 13$ cell lines, however $\mathrm{IC}_{50}$ values could not be determined in the remaining five cell lines. We previously examined the effect of sorafenib in the same liver cancer cell lines and observed $\mathrm{IC}_{50}$ values ranging from 2.1 to $4.3 \mu \mathrm{M}$ [(24) for KIM-1 and HAK-1B, data not shown for others]. Yamamoto et al. also examined the suppressive effect of lenvatinib on cell proliferation in vitro using lung cancer and colon cancer cell lines, in which the $\mathrm{IC}_{50}$ values ranged from approximately 20 to $30 \mu \mathrm{M}$ (13); in addition, the $\mathrm{IC}_{50}$ values for lenvatinib were relatively higher than those for sorafenib.

Our analysis on the expression of growth-related factors indicated that cell lines showing high response to lenvatinib expressed growth-related factors in abundance including RET, FGFRs and FGF19. Because lenvatinib is a potent inihibitor of tyrosine receptor kinases including RET and FGFRs, the inhibitory action of lenvatinib may depend upon the expression of growth-related factors. RET was most highly expressed in HAK-5 cells among the cell lines studied, whose $\mathrm{IC}_{50}$ value was the lowest in response to treatment of lenvatinib. Lenvatinib was shown to be effective in thyroid cancer (25), where RET is highly expressed and is known to be highly mutated $(26,27)$. However, in contrast to some studies reporting that RET is highly mutated in thyroid cancer, Kato et al. reported that in the analysis of aberrations including RET mutations and amplifications, aberrations were only observed in $88(1.8 \%)$ of 4,871 cases of other cancer types and of them, aberrations were observed only in one of 44 types of HCC (28). The frequency of RET aberrations is low in other types of cancer and the effect of lenvatinib via RET inhibition may be limited to some cases. The expression of RET protein was observed in response to lenvatinib; therefore, analyses of both mutations and protein levels of RET need to be performed.

In our previous study using six out of these 13 cell lines, FGF2 and FGFRs expression was detected and cell proliferation was suppressed by an FGF2-neutralizing antibody (23); therefore, FGF2 and FGFRs have been shown to be involved in the proliferation of HCC cells. The proliferation of liver cancer cells may have been suppressed by the direct interaction of lenvatinib with cancer cells via FGFR in vitro. The growth of some HCC is considered to be related to the signal transduction system of FGFs and FGFRs $(29,30)$. It has been reported that the expression of FGFR4, 


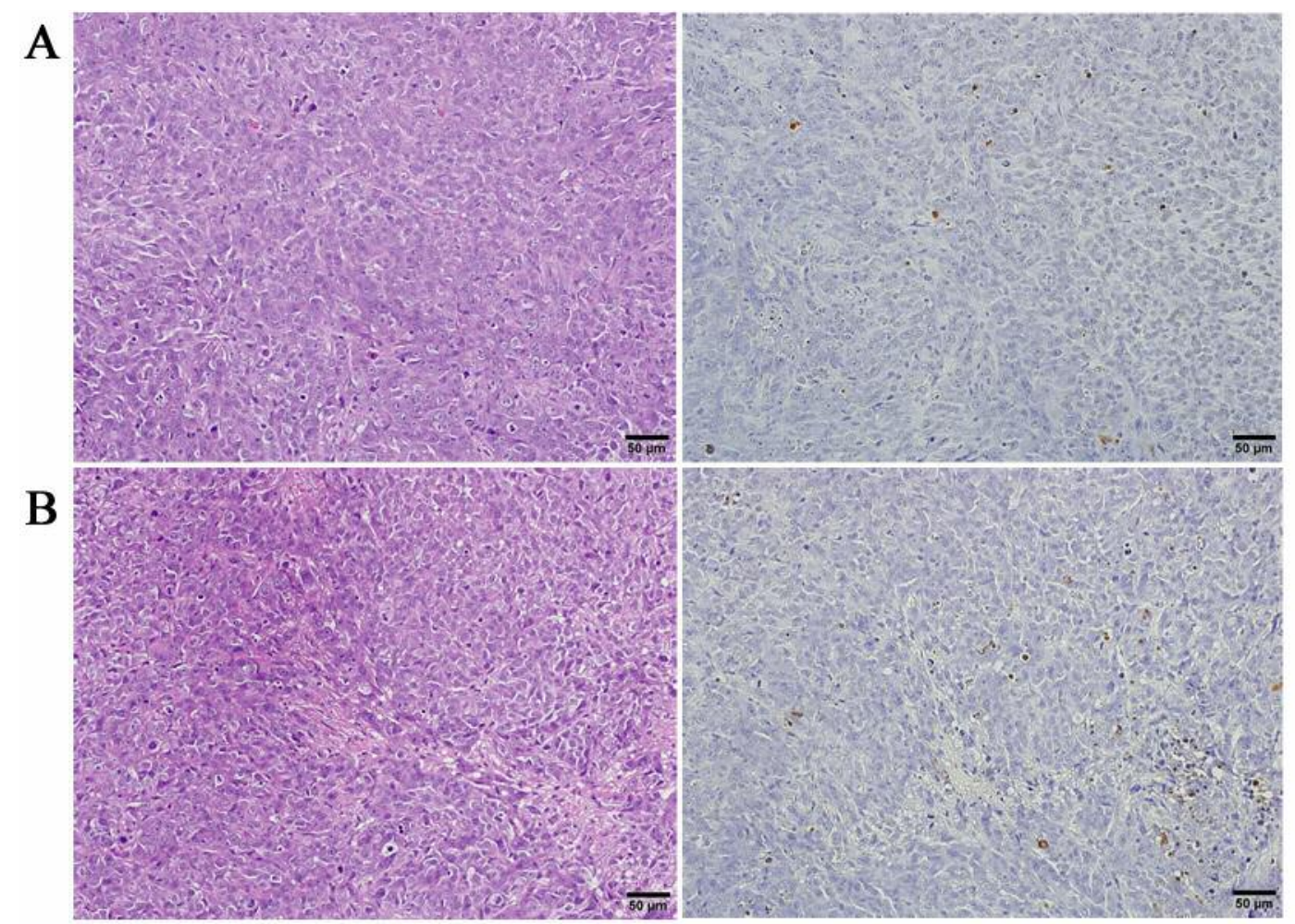

Figure 5. Analysis of lenvatinib-induced apoptosis in human hepatocellular carcinoma tumor HAK-1B subcutaneously transplanted in a nude mouse that received vehicle $(A)$ and in a mouse that received $30 \mathrm{mg} / \mathrm{kg}$ of lenvatinib (B). Left panel: Hematoxylin and eosin staining. Right panel: Staining by the TUNEL technique. Scale bar=50 $\mu \mathrm{m}$.

which is involved in angiogenesis, is found in one-third of HCC cases (31-33). Since there are few inhibitors of FGFR4 (34), drugs such as lenvatinib that reliably inhibit FGFR are useful for the treatment of HCC.

Although lenvatinib did not induce apoptosis of liver cancer cells in vitro or in vivo in this study, it has been reported to do so in thyroid cancer (35) and nasopharyngeal carcinoma (36). Lenvatinib-induced apoptosis appears to be cancer type specific.

We observed suppression of tumor growth and angiogenesis with lenvatinib treatment and an increase in the rate of necrosis of KYN-2 and HAK-1B HCC cells implanted in mice in vivo. In our previous study on sorafenib in the same liver cancer cell lines, $\mathrm{IC}_{50}$ values were obtained for all 13 cell lines and apoptosis was induced in 8/13 cell lines in vitro [(24) for KIM-1and HAK-1B, data not shown for others]. Both tumor volume and tumor weight only decreased to $50 \%$ with sorafenib administration in mice transplanted with KYN-2 cells (37); whereas, a decrease to below 30\% was observed with lenvatinib administration. The vascular density did not decrease to below $50 \%$ with sorafenib administration, but decreased to $14 \%$ with lenvatinib administration. We found the effect of lenvatinib to be inferior to that of sorafenib in the suppression of cell growth in vitro, but superior in tumor-growth suppression in vivo. Type I to $\mathrm{V}$ kinase inhibitors binding to VEGFR2 have been reported, of which sorafenib is a type II (38) and lenvatinib a type V inhibitor (39). Type $\mathrm{V}$ inhibitors are reported to possess faster binding and higher affinity for VEGFR2, making their kinase-inhibitory activities stronger compared to type II inhibitors. FGFR signaling increases VEGF as well as VEGFR, and when VEGF and VEGFR are suppressed, FGF production is activated to enhance FGFR signaling, which causes VEGFR and FGFR to cooperatively promote tumor angiogenesis (40). Therefore, we presume that the suppressive effect of lenvatinib on angiogenesis was exerted by quickly binding to factors (such as VEGFR and FGFR) involved in tumor angiogenesis with increased affinity, which led to the highly suppressive effect on tumor growth in vivo, likely by the indirect activity of lenvatinib rather than its direct activity.

In conclusion, our study suggests that lenvatinib exhibits an antitumor effect mainly by suppressing angiogenesis, but it may directly suppress cell proliferation in cells with high FGFR expression. 

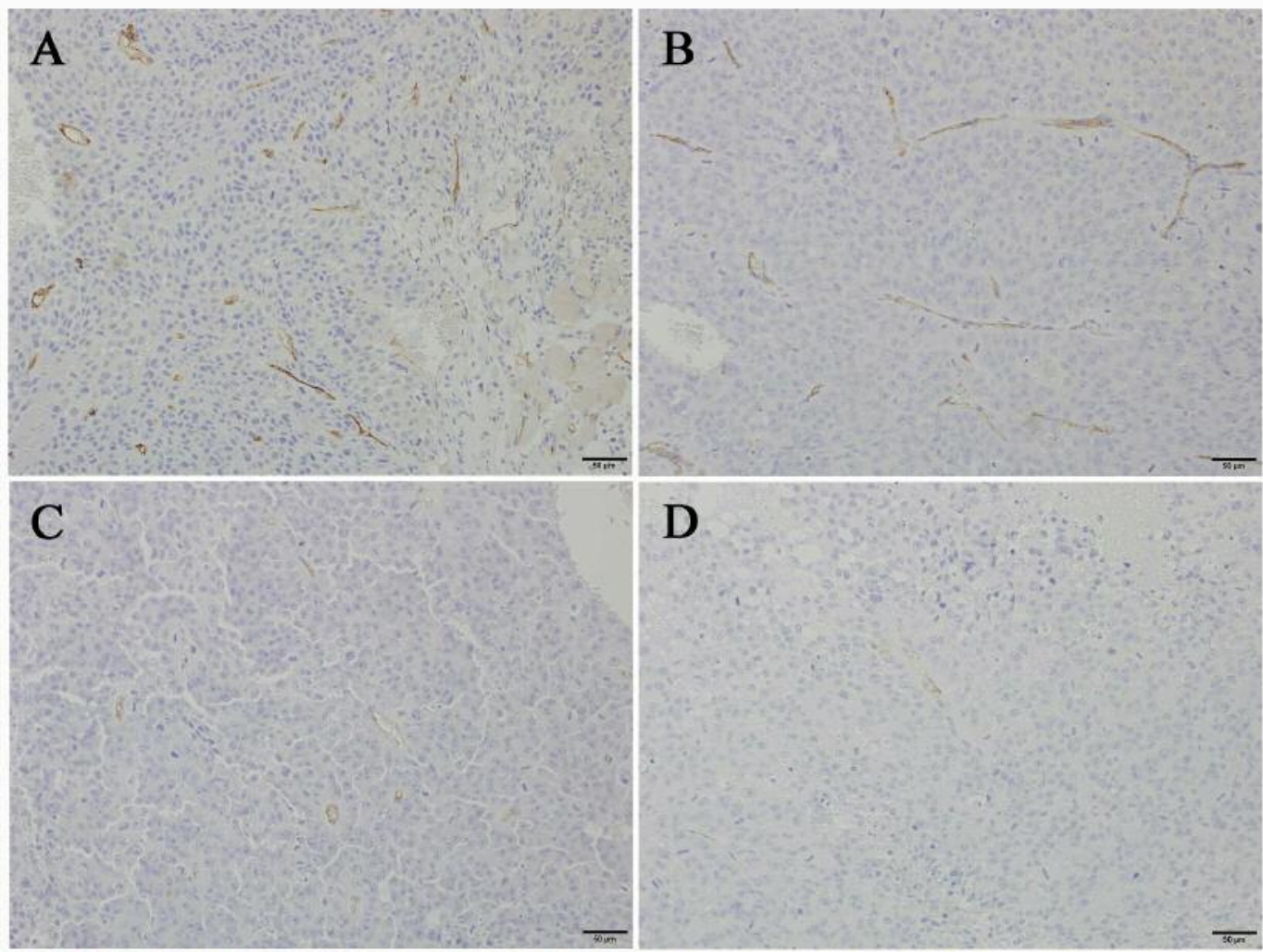

D
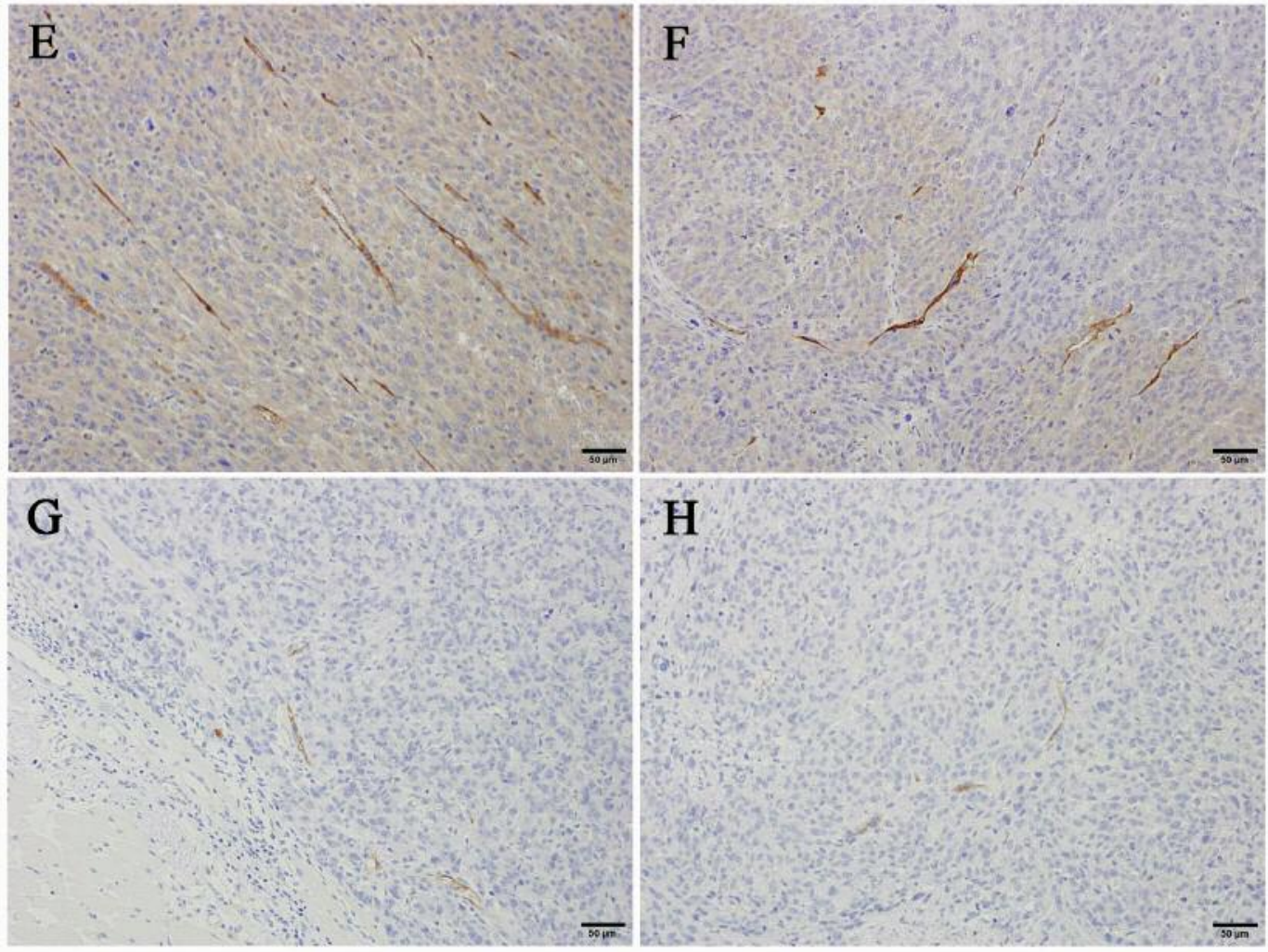

Figure 6. Effect of lenvatinib on suppression of angiogenesis in tumors developed after subcutaneous transplantation of hepatocellular carcinoma cells. Immunohistochemical staining of CD34 in KYN-2 cell tumors $(A-D)$ and HAK-1B cell tumors $(E-H)$. Scale bar $=50 \mu m$. Mice received vehicle (control) $(A, E)$, or lenvatinib of at $3(B, F), 10(C, G)$, or $(D, H) 30 \mathrm{mg} / \mathrm{kg} / \mathrm{mouse} /$ day. 
A

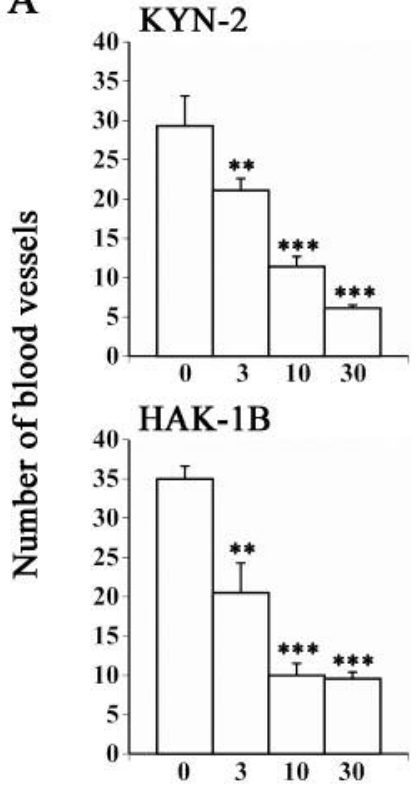

Lenvatinib (mg/kg)
B
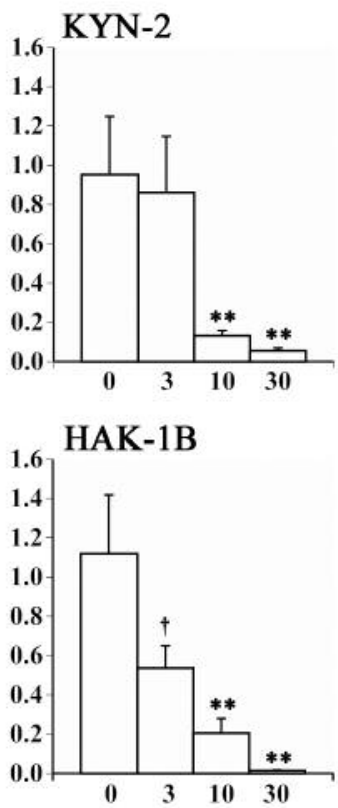

Lenvatinib (mg/kg)

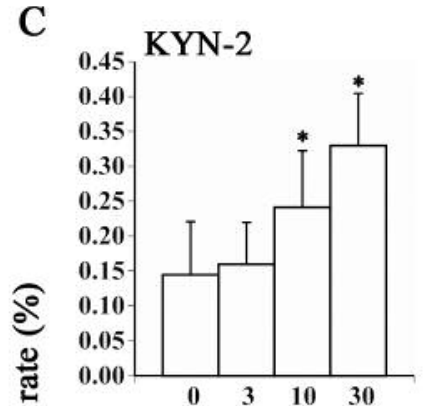

HAK-1B

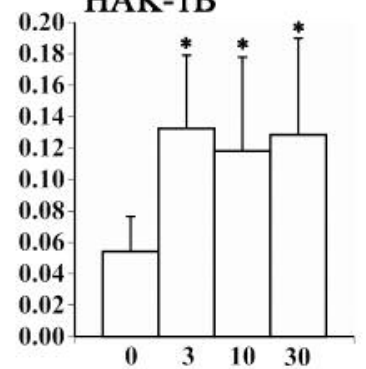

Lenvatinib ( $\mathrm{mg} / \mathrm{kg})$

Figure 7. Effect of lenvatinib on blood vessel frequency $(A)$, microvessel density $(B)$, and necrosis rate of tumors $(C)$ in nude mice. Figures represent the average $\pm S D$. Significantly different at $* p<0.05$, ** $p<0.01$, or $* * * p<0.001$ vs. control.

\section{Conflicts of Interest}

The Authors have no conflicts of interest to disclose.

\section{Authors' Contributions}

Sachiko Ogasawara: Performed the entire experiment. Article preparation and submission. Yutaro Mihara: Cooperation in animal experiments. Reiichiro Kondo: Cooperation in examination of tissue specimens. Hironori Kusano: Cooperation in examination of tissue specimens. Jun Akiba: Input in evaluating results. Hirohisa Yano: Input in evaluating results.

\section{Acknowledgements}

The Authors gratefully acknowledge Ms. Akemi Fujiyoshi, Ms. Sachiyo Maeda and Ms. Akiko Tanaka for their assistance in our experiment.

\section{References}

1 Ferlay J, Soerjomataram I, Dikshit R, Eser S, Mathers C, Rebelo M, Parkin DM, Forman D and Bray F: Cancer incidence and mortality worldwide: Sources, methods and major patterns in globocan 2012. Int J Cancer 136(5): E359-386, 2015. PMID: 25220842. DOI: $10.1002 / \mathrm{ijc} .29210$

2 Torre LA, Bray F, Siegel RL, Ferlay J, Lortet-Tieulent J and Jemal A: Global cancer statistics, 2012. CA Cancer J Clin 65(2): 87-108, 2015. PMID: 25651787. DOI: 10.3322/caac.21262
3 Semela D and Dufour JF: Angiogenesis and hepatocellular carcinoma. J Hepatol 41(5): 864-880, 2004. PMID: 15519663. DOI: $10.1016 /$ j.jhep.2004.09.006

4 Wilhelm SM, Carter C, Tang L, Wilkie D, McNabola A, Rong H, Chen C, Zhang X, Vincent P, McHugh M, Cao Y, Shujath J, Gawlak S, Eveleigh D, Rowley B, Liu L, Adnane L, Lynch M, Auclair D, Taylor I, Gedrich R, Voznesensky A, Riedl B, Post LE, Bollag G and Trail PA: Bay 43-9006 exhibits broad spectrum oral antitumor activity and targets the RAF/MEK/ERK pathway and receptor tyrosine kinases involved in tumor progression and angiogenesis. Cancer Res 64: 7099-7109, 2004. PMID: 15466206. DOI: 10.1158/00085472.CAN-04-1443

5 Tohyama O, Matsui J, Kodama K, Hata-Sugi N, Kimura T, Okamoto K, Minoshima Y, Iwata M and Funahashi Y: Antitumor activity of lenvatinib (e7080): An angiogenesis inhibitor that targets multiple receptor tyrosine kinases in preclinical human thyroid cancer models. J Thyroid Res 2014: 638747, 2014. PMID: 25295214. DOI: 10.1155/2014/638747

6 Llovet JM, Ricci S, Mazzaferro V, Hilgard P, Gane E, Blanc JF, de Oliveira AC, Santoro A, Raoul JL, Forner A, Schwartz M, Porta C, Zeuzem S, Bolondi L, Greten TF, Galle PR, Seitz JF, Borbath I, Haussinger D, Giannaris T, Shan M, Moscovici M, Voliotis D, Bruix $\mathbf{J}$ and Group SIS: Sorafenib in advanced hepatocellular carcinoma. N Engl J Med 359(4): 378-390, 2008. PMID: 18650514. DOI: 10.1056/NEJMoa0708857

7 Cheng A-L, Kang Y-K, Chen Z, Tsao C-J, Qin S, Kim JS, Luo R, Feng J, Ye S, Yang T-S, Xu J, Sun Y, Liang H, Liu J, Wang J, Tak WY, Pan H, Burock K, Zou J, Voliotis D and Guan Z: Efficacy and safety of sorafenib in patients in the Asia-Pacific 
region with advanced hepatocellular carcinoma: A phase III randomised, double-blind, placebo-controlled trial. Lancet Oncol 10(1): 25-34, 2009. PMID: 19095497. DOI: $10.1016 / \mathrm{s} 1470-2045$ (08) 70285-7

8 Cheng AL, Kang YK, Lin DY, Park JW, Kudo M, Qin S, Chung HC, Song X, Xu J, Poggi G, Omata M, Pitman Lowenthal S, Lanzalone S, Yang L, Lechuga MJ and Raymond E: Sunitinib versus sorafenib in advanced hepatocellular cancer: Results of a randomized phase III trial. J Clin Oncol 31(32): 4067-4075, 2013. PMID: 24081937. DOI: 10.1200/JCO.2012.45.8372

9 Johnson PJ, Qin S, Park JW, Poon RT, Raoul JL, Philip PA, Hsu $\mathrm{CH}, \mathrm{Hu} \mathrm{TH}$, Heo J, Xu J, Lu L, Chao Y, Boucher E, Han KH, Paik SW, Robles-Avina J, Kudo M, Yan L, Sobhonslidsuk A, Komov D, Decaens T, Tak WY, Jeng LB, Liu D, Ezzeddine R, Walters I and Cheng AL: Brivanib versus sorafenib as first-line therapy in patients with unresectable, advanced hepatocellular carcinoma: Results from the randomized phase III BRISK-FL study. J Clin Oncol 31(28): 3517-3524, 2013. PMID: 23980084. DOI: $10.1200 / \mathrm{JCO} .2012 .48 .4410$

10 Cainap C, Qin S, Huang WT, Chung IJ, Pan H, Cheng Y, Kudo M, Kang YK, Chen PJ, Toh HC, Gorbunova V, Eskens FA, Qian J, McKee MD, Ricker JL, Carlson DM and El-Nowiem S: Linifanib versus sorafenib in patients with advanced hepatocellular carcinoma: Results of a randomized phase III trial. J Clin Oncol 33(2): 172-179, 2015. PMID: 25488963. DOI: 10.1200/JCO.2013.54.3298

11 Zhu AX, Rosmorduc O, Evans TR, Ross PJ, Santoro A, Carrilho FJ, Bruix J, Qin S, Thuluvath PJ, Llovet JM, Leberre MA, Jensen M, Meinhardt G and Kang YK: Search: A phase III, randomized, double-blind, placebo-controlled trial of sorafenib plus erlotinib in patients with advanced hepatocellular carcinoma. J Clin Oncol 33(6): 559-566, 2015. PMID: 25547503. DOI: $10.1200 / \mathrm{JCO} .2013 .53 .7746$

12 Matsui J, Funahashi Y, Uenaka T, Watanabe T, Tsuruoka A and Asada M: Multi-kinase inhibitor e7080 suppresses lymph node and lung metastases of human mammary breast tumor MDAMB-231 via inhibition of vascular endothelial growth factorreceptor (VEGF-R) 2 and VEGF-R3 kinase. Clin Cancer Res 14(17): 5459-5465, 2008. PMID: 18765537. DOI: 10.1158/ 1078-0432.CCR-07-5270

13 Yamamoto Y, Matsui J, Matsushima T, Obaishi H, Miyazaki K, Nakamura K, Tohyama O, Semba T, Yamaguchi A, Hoshi SS, Mimura F, Haneda T, Fukuda Y, Kamata JI, Takahashi K, Matsukura M, Wakabayashi T, Asada M, Nomoto KI, Watanabe T, Dezso Z, Yoshimatsu K, Funahashi Y and Tsuruoka A: Lenvatinib, an angiogenesis inhibitor targeting VEGFR/FGFR, shows broad antitumor activity in human tumor xenograft models associated with microvessel density and pericyte coverage. Vasc Cell 6: 18, 2014. PMID: 25197551. DOI: 10.1186/2045-824X-6-18

14 Kudo M, Finn RS, Qin S, Han KH, Ikeda K, Piscaglia F, Baron A, Park JW, Han G, Jassem J, Blanc JF, Vogel A, Komov D, Evans TRJ, Lopez C, Dutcus C, Guo M, Saito K, Kraljevic S, Tamai T, Ren M and Cheng AL: Lenvatinib versus sorafenib in first-line treatment of patients with unresectable hepatocellular carcinoma: A randomised phase 3 non-inferiority trial. Lancet 391(10126): 1163-1173, 2018. PMID: 29433850. DOI: 10.1016/ s0140-6736(18)30207-1

15 Murakami T: Establishment and characterization of human hepatoma cell line (KIM-1). Act Hepatol Jpn 25: 532-539, 1984.
16 Yano H, Maruiwa M, Murakami T, Fukuda K, Ito Y, Sugihara S and Kojiro M: A new human pleomorphic hepatocellular carcinoma cell line, KYN-2. Acta Pathol Jpn 38(8): 953-966, 1988. PMID: 2847482. DOI: 10.1111/j.1440-1827.1988.tb02 368.x

17 Murakami T, Maruiwa M, Fukuda K, Kojiro M, Tanaka M and Tanikawa K: Establishment and characterization of a new human hepatoma cell line $(\mathrm{KYN}-3)$ derived from the ascites of the hepatoma patient (Abstract). Jpn J Cancer Res Proc Jpn Cancer Assoc 292, 1988.

18 Yano H, Iemura A, Fukuda K, Mizoguchi A, Haramaki M and Kojiro M: Establishment of two distinct human hepatocellular carcinoma cell lines from a single nodule showing clonal dedifferentiation of cancer cells. Hepatology 18(2): 320-327, 1993. PMID: 8393423.

19 Haramaki M, Yano H, Iemura A, Momosaki S, Ogasawara S, Inoue M, Yamaguchi R, Kusaba A, Utsunomiya I and Kojiro M: A new human hepatocellular carcinoma cell line (HAK-2) forms various structures in collagen gel matrices. Hum Cell 10(3): 183192, 1997. PMID: 9436038.

20 Utsunomiya I, Iemura A, Yano H, Akiba J and Kojiro M: Establishment and characterization of a new human hepatocellular carcinoma cell line, HAK-3, and its response to growth factors. Int J Oncol 15(4): 669-675, 1999. PMID: 10493947. DOI: 10.3892/ijo.15.4.669

21 Murakami T, Yano H, Maruiwa M, Sugihara S and Kojiro M: Establishment and characterization of a human combined hepatocholangiocarcinoma cell line and its heterologous transplantation in nude mice. Hepatology 7(3): 551-556, 1987. PMID: 3032760. DOI: 10.1002/hep.1840070322

22 Yano H, Iemura A, Haramaki M, Momosaki S, Ogasawara S, Higaki K and Kojiro M: A human combined hepatocellular and cholangiocarcinoma cell line $(\mathrm{KMCH}-2)$ that shows the features of hepatocellular carcinoma or cholangiocarcinoma under different growth conditions. J Hepatol 24(4): 413-422, 1996. PMID: 8738727. DOI: 10.1016/s0168-8272(96)80161-9

23 Ogasawara S, Yano H, Iemura A, Hisaka T and Kojiro M: Expressions of basic fibroblast growth factor and its receptors and their relationship to proliferation of human hepatocellular carcinoma cell lines. Hepatology 24(1): 198-205, 1996. PMID: 8707262. DOI: $10.1053 /$ jhep.1996.v24.pm0008707262

24 Kusano H, Ogasawara S, Akiba J, Nakayama M, Ueda K and Yano H: Antiproliferative effects of sorafenib and pegylated IFNalpha2b on human liver cancer cells in vitro and in vivo. Int J Oncol 42(6): 1897-1903, 2013. PMID: 23588838. DOI: 10.3892/ijo.2013.1904

25 Schlumberger M, Tahara M, Wirth LJ, Robinson B, Brose MS, Elisei R, Habra MA, Newbold K, Shah MH, Hoff AO, Gianoukakis AG, Kiyota N, Taylor MH, Kim SB, Krzyzanowska MK, Dutcus CE, de las Heras B, Zhu J and Sherman SI: Lenvatinib versus placebo in radioiodine-refractory thyroid cancer. N Engl J Med 372(7): 621-630, 2015. PMID: 25671254. DOI: $10.1056 /$ NEJMoa1406470

26 Elisei R, Cosci B, Romei C, Bottici V, Renzini G, Molinaro E, Agate L, Vivaldi A, Faviana P, Basolo F, Miccoli P, Berti $\mathrm{P}$, Pacini $\mathrm{F}$ and Pinchera A: Prognostic significance of somatic ret oncogene mutations in sporadic medullary thyroid cancer: A 10-year follow-up study. J Clin Endocrinol Metab 93(3): 682-687, 2008. PMID: 18073307. DOI: $10.1210 /$ jc. $2007-1714$ 
27 Moura MM, Cavaco BM, Pinto AE, Domingues R, Santos JR, Cid MO, Bugalho MJ and Leite V: Correlation of RET somatic mutations with clinicopathological features in sporadic medullary thyroid carcinomas. Br J Cancer 100(11): 1777-1783, 2009. PMID: 19401695. DOI: 10.1038/sj.bjc.6605056

28 Kato S, Subbiah V, Marchlik E, Elkin SK, Carter JL and Kurzrock R: RET aberrations in diverse cancers: Next-generation sequencing of 4,871 patients. Clin Cancer Res 23(8): 1988-1997, 2017. PMID: 27683183. DOI: 10.1158/1078-0432.CCR-16-1679

29 Sandhu DS, Baichoo E and Roberts LR: Fibroblast growth factor signaling in liver carcinogenesis. Hepatology 59(3): 1166-1173, 2014. PMID: 24716202. DOI: 10.1002/hep.26679

30 Matsuki M, Hoshi T, Yamamoto Y, Ikemori-Kawada M, Minoshima Y, Funahashi Y and Matsui J: Lenvatinib inhibits angiogenesis and tumor fibroblast growth factor signaling pathways in human hepatocellular carcinoma models. Cancer Med 7(6): 2641-2653, 2018. PMID: 29733511. DOI: 10.1002/cam4.1517

31 Repana D and Ross P: Targeting FGF19/FGFR4 pathway: A novel therapeutic strategy for hepatocellular carcinoma. Diseases 3(4): 294-305, 2015. PMID: 28943626. DOI: 10.3390/diseases3040294

32 French DM, Lin BC, Wang M, Adams C, Shek T, Hotzel K, Bolon B, Ferrando R, Blackmore C, Schroeder K, Rodriguez LA, Hristopoulos M, Venook R, Ashkenazi A and Desnoyers LR: Targeting FGFR4 inhibits hepatocellular carcinoma in preclinical mouse models. PLoS One 7(5): e36713, 2012. PMID: 22615798. DOI: 10.1371/journal.pone.0036713

33 Ho HK, Pok S, Streit S, Ruhe JE, Hart S, Lim KS, Loo HL, Aung MO, Lim SG and Ullrich A: Fibroblast growth factor receptor 4 regulates proliferation, anti-apoptosis and alphafetoprotein secretion during hepatocellular carcinoma progression and represents a potential target for therapeutic intervention. J Hepatol 50(1): 118-127, 2009. PMID: 19008009. DOI: $10.1016 /$ j.jhep.2008.08.015

34 Babina IS and Turner NC: Advances and challenges in targeting FGFR signalling in cancer. Nat Rev Cancer 17(5): 318-332, 2017. PMID: 28303906. DOI: $10.1038 /$ nrc.2017.8
35 Ferrari SM, Bocci G, Di Desidero T, Elia G, Ruffilli I, Ragusa F, Orlandi P, Paparo SR, Patrizio A, Piaggi S, La Motta C, Ulisse S, Baldini E, Materazzi G, Miccoli P, Antonelli A and Fallahi P: Lenvatinib exhibits antineoplastic activity in anaplastic thyroid cancer in vitro and in vivo. Oncol Rep 39(5): 2225-2234, 2018. PMID: 29517103. DOI: 10.3892/or.2018.6306

36 Wang G, Zhuang J, Ni J, Ye Y, He S and Xia W: Combined effects of lenvatinib and iodine-131 on cell apoptosis in nasopharyngeal carcinoma through inducing endoplasmic reticulum stress. Exp Ther Med 16(4): 3325-3332, 2018. PMID: 30233679. DOI: $10.3892 / \mathrm{etm} .2018 .6652$

37 Ogasawara S, Nakayama M, Akiba J, Kusano H and Yano H: Effect of sorafenib on des-gamma-carboxyprothrombin secretion by a human hepatocellular carcinoma cell line. Oncol Lett 14(2): 2170-2176, 2017. PMID: 28781657. DOI: 10.3892/ol.2017.6451

38 Kufareva I and Abagyan R: Type-II kinase inhibitor docking, screening, and profiling using modified structures of active kinase states. J Med Chem 51(24): 7921-7932, 2008. PMID: 19053777. DOI: $10.1021 /$ jm8010299

39 Okamoto K, Ikemori-Kawada M, Jestel A, von Konig K, Funahashi Y, Matsushima T, Tsuruoka A, Inoue A and Matsui J: Distinct binding mode of multikinase inhibitor lenvatinib revealed by biochemical characterization. ACS Med Chem Lett 6(1): 89-94, 2015. PMID: 25589937. DOI: 10.1021/ml500394m

40 Seghezzi G, Patel S, Ren CJ, Gualandris A, Pintucci G, Robbins ES, Shapiro RL, Galloway AC, Rifkin DB and Mignatti P: Fibroblast growth factor-2 (FGF-2) induces vascular endothelial growth factor (VEGF) expression in the endothelial cells of forming capillaries: An autocrine mechanism contributing to angiogenesis. J Cell Biol 141(7): 1659-1673, 1998. PMID: 9647657. DOI: $10.1083 /$ jcb.141.7.1659

Received October 1, 2019

Revised October 17, 2019

Accepted October 21, 2019 